\title{
Effects of Lizardite Addition on Technological Properties of Forsterite-Monticellite Rich White Ceramics Prepared From Natural Magnesite and Dolomite
}

\section{Research Article}

Keywords:

Posted Date: November 11th, 2020

DOl: https://doi.org/10.21203/rs.3.rs-102638/v2

License: (1) This work is licensed under a Creative Commons Attribution 4.0 International License. Read Full License

Version of Record: A version of this preprint was published at Journal of Construction Research on February 9th, 2021. See the published version at https://doi.org/10.30564/jcr.v2i1.2684. 


\section{Abstract}

The authors have requested that this preprint be withdrawn due to erroneous posting.

\section{Full Text}

The authors have withdrawn this preprint from Research Square. 